\title{
PROCESSING OF SPENT ZINC-MnO, DRY CELLS IN VARIOUS ACIDIC MEDIA
}

\author{
Vinício Francisco Ibiapina ${ }^{\mathrm{a}}$, Ulysses dos Santos Florentino ${ }^{\mathrm{a}}$, Júlio Carlos Afonso ${ }^{\mathrm{a}, *}$, Valdir Gante ${ }^{\mathrm{b}}$, Cláudio Augusto Vianna ${ }^{\mathrm{b}}$ \\ and José Luiz Mantovano ${ }^{b}$ \\ aDepartamento de Química Analítica, Instituto de Química, Universidade Federal do Rio de Janeiro, 21941-909 Rio de Janeiro \\ - RJ, Brasil \\ bDepartamento de Química e Materiais Nucleares, Instituto de Engenharia Nuclear, 21941-906 Rio de Janeiro - RJ, Brasil
}

Recebido em 30/08/2017; aceito em 06/11/2017; publicado na web em 04/12/2017

\begin{abstract}
This paper describes a route for recovering manganese and zinc from spent zinc- $\mathrm{MnO}_{2}$ dry cells via acid leaching. Sulfuric, hydrofluoric and formic acids were used as leachants. Hydrogen peroxide was added as reductant, except for formic acid since it is itself a reductant. Experiments were run at $25-40{ }^{\circ} \mathrm{C}$ for $1-3 \mathrm{~h}$. Under the best optimal conditions, over $95 \mathrm{wt} . \%$ of zinc and manganese were leached irrespective of the leachant. Leaching of contaminants was strongly dependent on the leachant due to the insolubility of salts or complexing reactions. $\mathrm{Zn}$ (II) was best extracted with D2EHPA diluted in n-heptane at $\mathrm{pH}>1$, particularly from the leachates of weak acids. $\mathrm{Mn}(\mathrm{II})$ was much more co-extracted from sulfuric leachates, but was easily scrubbed with dilute leachant $\left.(\sim 2 \mathrm{~mol} \mathrm{~L})^{-1}\right)$. $\mathrm{Zn}$ (II) striping was possible using $5 \mathrm{~mol} \mathrm{~L}^{-1} \mathrm{H}_{2} \mathrm{SO}_{4}$. Manganese was isolated as $\mathrm{MnO}_{2}$ carrying the leached contaminants. High-purity sodium salts of the anions of the leachants were recovered after slow evaporation of the final solution.
\end{abstract}

Keywords: zinc- $\mathrm{MnO}_{2}$ dry cells; acid leaching; zinc extraction; manganese precipitation; sodium salts.

\section{INTRODUCTION}

In the last decades the consumption of batteries has increased because of their versatility, low maintenance, reduced cost and high demand from the electronics industry. ${ }^{1,2}$ The most commonly used types of batteries are the zinc- $\mathrm{MnO}_{2}$ dry cells (Leclanché and alkaline). ${ }^{3-6}$ They are usually chosen for objects where small quantities of power are required. ${ }^{7}$ These batteries are not rechargeable and usually run out rapidly. ${ }^{6,8}$

Disposal of spent zinc- $\mathrm{MnO}_{2}$ batteries has become an environmental challenge. Currently, a significant amount of spent zinc- $\mathrm{MnO}_{2}$ dry cells is still dumped in landfills or even incinerated. ${ }^{3,8-10}$ They constitute an important source of metal pollution in landfill leachates. ${ }^{1-4,11-13}$ Incineration releases toxic gases that must be cleaned by off-gas treatment systems; also, recyclable materials are lost. ${ }^{2}$

Recycling of spent zinc- $\mathrm{MnO}_{2}$ dry cells is the best choice to handle this residue from an environmental point of view, and has also become an urgent matter for resource saving. ${ }^{14-17}$ They have been regarded as a secondary source of zinc and manganese..$^{9,15,18,19}$ Due to the rising demand and limited supply from natural sources, manganese and zinc have been listed among the strategic metals by many countries. ${ }^{20,21}$

Preliminary physical separation methods followed by pyro ${ }^{20,21}$ or hydrometallurgical treatments, ${ }^{4,18,22-24}$ are applicable to the recovery of valuable metals from zinc- $\mathrm{MnO}_{2}$ dry cells. Pyrometallurgical routes have negative effects on the environment because of emissions, secondary waste streams, energy consumption and hazardous work environments. ${ }^{6}{ }^{10}$ Hydrometallurgical routes tend to be less expensive and less energy consuming than pyrometallurgical methods. ${ }^{14,16,19}$ Sulfuric acid is by far the most used leachant. ${ }^{2,25-32}$ It provides high zinc recovery whereas most manganese remains in the insoluble residue (Mn(III) and $\mathrm{Mn}(\mathrm{IV})$ compounds). A reductant (such as hydrogen peroxide, sulfur dioxide, oxalic acid, carbohydrates etc.) is necessary to bring all manganese to $2+$ state, which is soluble and stable in acidic medium. ${ }^{33,34}$ Hydrochloric acid has also been reported, ${ }^{19,35}$ but it is oxidized by $\mathrm{Mn}(\mathrm{III})$ and $\mathrm{Mn}(\mathrm{IV})$ producing

*e-mail: julio@iq.ufrj.br dichlorine $\left(\mathrm{Cl}_{2}\right)$, a toxic gas. Other reported draw-backs of the routes proposed so far are high recovery processing requirements, long time, low value-added products and high chemicals consumption. ${ }^{2,11,21}$ Therefore, new processes for recycling spent zinc- $\mathrm{MnO}_{2}$ dry cells need to be developed.

Apparently, no mention has been made to hydrofluoric acid. Fluoride is a very hard base and forms very stable complexes with cations with noble gas-like configuration (the so-called hard acids). This is generally found in cations with a high charge and a small ionic radius, like $\mathrm{Al}^{3+}$ and $\mathrm{Fe}^{3+} .36,37$ This feature is of particular interest because iron frequently contaminates the acidic leachates, thus making $\mathrm{Zn}$ (II) recovery more difficult. ${ }^{17,38}$ This acid has already been investigated as a leachant for spent catalysts. ${ }^{39,40}$

Different from many carboxylic acids (citric, malic, succinic, oxalic, iminodiacetic, tartaric) ${ }^{5,21}$ formic acid has apparently not been tested yet. Like oxalic acid, the simplest aliphatic monocarboxylic acid is a strong reductant, but does not precipitate metal ions as does oxalate. ${ }^{36,37}$ Therefore, formic acid can act both as a leachant and as a reductant. It has been acknowledged as a versatile renewable reagent for green and sustainable chemical synthesis and processes. ${ }^{41}$

Leached $\mathrm{Zn}(\mathrm{II})$ can be separated from $\mathrm{Mn}(\mathrm{II})$ by chemical precipitation, ${ }^{22,24}$ solvent extraction (SX) $)^{2,25-31,42}$ or electrowinning. ${ }^{16,24}$ Zn(II) extraction using D2EHPA (di-(2-ethylhexyl)phosphoric acid, a cation exchanger) has been studied since the 1980s. In general, $\mathrm{Zn}$ (II) is preferably extracted over $\mathrm{Mn}$ (II) in sulfuric acid medium, but the extraction curves may be close to each other according to the experimental conditions. ${ }^{26,28,29,42} \mathrm{SX}$ techniques have become essential to the hydrometallurgical processes due to the growing demand for high purity metals and the need to process low-grade ores with great complexity. ${ }^{42}$

The aim of this study was to carry out a complete investigation involving leaching of manganese and zinc from spent zinc- $\mathrm{MnO}_{2}$ dry cells under mild experimental conditions on lab-scale using a weak acid with reducing (formic acid) or complexing (hydrofluoric acid) properties. Sulfuric acid was employed for the sake of comparison. Experimental studies were carried out to assess the main factors that affect leaching efficiency. Zinc and manganese were separated by a 
combination of SX and precipitation techniques. The final solution was processed to recover the sodium salt of the anion of the leachant.

\section{EXPERIMENTAL}

\section{Materials}

Spent AA zinc- $\mathrm{MnO}_{2}$ dry cells (alkaline and Leclanché) were employed in this study. The AA format is the most current size employed in Brazil. Their expiration date was between March-July 2014. Alkaline and Leclanché dry cells were processed together. Twenty samples of each were manually dismantled (using gloves, glasses and dust masks). The active components (anode, cathode and electrolyte) were separated from other components such as plastic and paper films, ferrous and non-ferrous scraps and carbon rods. Samples were not calcined in order to recover carbon as insoluble matter. They were fed into a milling machine for size reduction $(100 \%<1 \mathrm{~mm}$, $30 \mathrm{~min}$ ). This mass was dried at $40^{\circ} \mathrm{C}$ for $24 \mathrm{~h}$.

$\mathrm{HF}$ (40 wt. $\left.\%, \sim 20 \mathrm{~mol} \mathrm{~L}^{-1}\right), \mathrm{H}_{2} \mathrm{SO}_{4}\left(49\right.$ wt. $\left.\%, \sim 9 \mathrm{~mol} \mathrm{~L}^{-1}\right), \mathrm{HCOOH}$ (formic acid) ( $\left.88 \mathrm{wt} . \%, \sim 20 \mathrm{~mol} \mathrm{~L}^{-1}\right)$ and $\mathrm{H}_{2} \mathrm{O}_{2}\left(30 \mathrm{wt} . \%, \sim 10 \mathrm{~mol} \mathrm{~L}^{-1}\right.$ ) were used without further purification.

The extractant D2EHPA (di-(2-ethylhexyl)phosphoric acid, Sigma-Aldrich) was used without further purification. n-Heptane (Sigma-Aldrich) was used as diluent.

The salts $\mathrm{ZnCl}_{2} \cdot 6 \mathrm{H}_{2} \mathrm{O}, \mathrm{ZnSO}_{4} \cdot 7 \mathrm{H}_{2} \mathrm{O}, \mathrm{ZnF}_{2}, \mathrm{Zn}(\mathrm{HCOO})_{2} \cdot 2 \mathrm{H}_{2} \mathrm{O}$, $\mathrm{MnCl}_{2} \cdot 4 \mathrm{H}_{2} \mathrm{O}, \mathrm{MnSO}_{4} \cdot \mathrm{H}_{2} \mathrm{O}, \mathrm{MnF}_{2}$ and $\mathrm{Mn}(\mathrm{HCOO})_{2} \cdot \mathrm{xH}_{2} \mathrm{O}$ were of analytical grade and used as received.

\section{Leaching procedure}

The experiments were run in triplicate and carried out in closed Teflon reactors under stirring (200 rotations per minute) for $1-3 \mathrm{~h}$ in a fume hood. Equal volumes of $\mathrm{H}_{2} \mathrm{O}_{2}$ and $\mathrm{HF}$ or $\mathrm{H}_{2} \mathrm{SO}_{4}$ or $\mathrm{H}_{2} \mathrm{O}$ and $\mathrm{HCOOH}$ were combined. The solid/liquid ratio was set at $100 \mathrm{~g} \mathrm{~L}^{-1}(10$ $\mathrm{g} \mathrm{mol}^{-1} \mathrm{HF}$ or $\mathrm{HCOOH} ; 22 \mathrm{~g} \mathrm{~mol}^{-1} \mathrm{H}_{2} \mathrm{SO}_{4} ; 20 \mathrm{~g} \mathrm{~mol}^{-1} \mathrm{H}_{2} \mathrm{O}_{2}$ ). Initial temperature was $25{ }^{\circ} \mathrm{C}$. After adding the dried mass, temperature increased by $10-15^{\circ} \mathrm{C}$ after $\sim 1 \mathrm{~h}$ in the presence of $\mathrm{H}_{2} \mathrm{O}_{2}$. Temperature decreased to $28-30{ }^{\circ} \mathrm{C}$ at the end of the experiment. No thermal effect was observed when formic acid was the leachant. In this case, slow heating was used during $1 \mathrm{~h}$ to $\sim 40{ }^{\circ} \mathrm{C}$, and then temperature was slowly decreased to $\sim 30{ }^{\circ} \mathrm{C}$ at the end of the experiment. Handling of acids (especially $\mathrm{HF}$ ) and $\mathrm{H}_{2} \mathrm{O}_{2}$ was performed using appropriate personal protective equipment.

The following equations describe the possible reactions of zinc metal and manganese/zinc oxides with values of $\Delta \mathrm{G}^{0}$ at $25^{\circ} \mathrm{C}:{ }^{43}$

$$
\begin{gathered}
\mathrm{Mn}_{2} \mathrm{O}_{3}+\mathrm{H}_{2} \mathrm{O}_{2}+4 \mathrm{HF} \rightarrow 2 \mathrm{MnF}_{2}+3 \mathrm{H}_{2} \mathrm{O}+\mathrm{O}_{2} \\
\Delta \mathrm{G}^{0}=-152.5 \mathrm{~kJ} \\
\mathrm{Mn}_{2} \mathrm{O}_{3}+\mathrm{H}_{2} \mathrm{O}_{2}+2 \mathrm{H}_{2} \mathrm{SO}_{4} \rightarrow 2 \mathrm{MnSO}_{4}+3 \mathrm{H}_{2} \mathrm{O}+\mathrm{O}_{2} \\
\Delta \mathrm{G}^{0}=-152.5 \mathrm{~kJ} \\
\mathrm{Mn}_{2} \mathrm{O}_{3}+5 \mathrm{HCOOH} \rightarrow 2 \mathrm{Mn}(\mathrm{HCOO})_{2}+3 \mathrm{H}_{2} \mathrm{O}+\mathrm{CO}_{2} \\
\Delta \mathrm{G}^{0}=-369.6 \mathrm{~kJ} \\
\mathrm{MnO}_{2}+\mathrm{H}_{2} \mathrm{O}_{2}+2 \mathrm{HF} \rightarrow \mathrm{MnF}_{2}+2 \mathrm{H}_{2} \mathrm{O}+\mathrm{O}_{2} \\
\Delta \mathrm{G}^{0}=-103.2 \mathrm{~kJ}^{2} \\
\mathrm{MnO}_{2}+\mathrm{H}_{2} \mathrm{O}_{2}+\mathrm{H}_{2} \mathrm{SO}_{4} \rightarrow \mathrm{MnSO}_{4}+2 \mathrm{H}_{2} \mathrm{O}+\mathrm{O}_{2} \\
\Delta \mathrm{G}^{0}=-103.2 \mathrm{~kJ} \\
\mathrm{MnO}_{2}+3 \mathrm{HCOOH}^{\rightarrow} \mathrm{Mn}\left(\mathrm{HCOO}_{2}+2 \mathrm{H}_{2} \mathrm{O}+\mathrm{CO}_{2}\right. \\
\Delta \mathrm{G}^{0}=-320.3 \mathrm{~kJ} \\
\mathrm{MnO}+2 \mathrm{HX} \rightarrow \mathrm{MnX}_{2}+\mathrm{H}_{2} \mathrm{O}(\mathrm{HX}=\mathrm{HF} \text { or HCOOH}) \\
\Delta \mathrm{G}^{0}=-232.5 \mathrm{~kJ} \\
\mathrm{ZnO}+2 \mathrm{HX} \rightarrow \mathrm{ZnX}_{2}+\mathrm{H}_{2} \mathrm{O}(\mathrm{HX}=\mathrm{HF} \text { or HCOOH}) \\
\Delta \mathrm{G}^{0}=-211.2 \mathrm{~kJ} \\
\mathrm{MnO}+\mathrm{H}_{2} \mathrm{SO}_{4} \rightarrow \mathrm{MnSO}_{4}+\mathrm{H}_{2} \mathrm{O}
\end{gathered}
$$

$$
\begin{gathered}
\Delta \mathrm{G}^{0}=-232.5 \mathrm{~kJ} \\
\mathrm{ZnO}+\mathrm{H}_{2} \mathrm{SO}_{4} \rightarrow \mathrm{ZnSO}_{4}+\mathrm{H}_{2} \mathrm{O} \\
\Delta \mathrm{G}^{0}=-211.2 \mathrm{~kJ} \\
\mathrm{Zn}+2 \mathrm{HX} \rightarrow \mathrm{ZnX}_{2}+\mathrm{H}_{2}(\mathrm{HX}=\mathrm{HF} \text { or } \mathrm{HCOOH}) \\
\Delta \mathrm{G}^{0}=-147.1 \mathrm{~kJ} \\
\mathrm{Zn}+\mathrm{H}_{2} \mathrm{SO}_{4} \rightarrow \mathrm{ZnSO}_{4}+\mathrm{H}_{2} \\
\Delta \mathrm{G}^{0}=-147.1 \mathrm{~kJ}
\end{gathered}
$$

All calculated values of $\Delta \mathrm{G}^{0}$ are negative. It follows that the reactions occur with high probability in the direction of product formation under the temperature range used, as described earlier.

The solid residue was separated from the leachate by filtration under vacuum. It was washed with water until $\mathrm{pH}$ 5.5. The washings were added to the leachate. The washed solid was dried at $150{ }^{\circ} \mathrm{C}$ for $3 \mathrm{~h}$, cooled down in a desiccator and weighed. The dried solids were then placed in ceramic crucibles and went through an oxidation step in air $\left(600^{\circ} \mathrm{C}, 3 \mathrm{~h}\right)$ in a furnace in order to eliminate carbon and other volatile components present. The gaseous effluent of the furnace was passed through distilled water at $25^{\circ} \mathrm{C}$. The roasted mass was cooled down in the furnace and weighed.

\section{Procedure for solvent extraction (SX)}

All SX experiments were performed at $25^{\circ} \mathrm{C}$. The aqueous/ organic (A/O) phase ratio was set at $1 \mathrm{v} / \mathrm{v}$. D2EHPA concentration varied from 3 to $16 \mathrm{vol} . \%$. $\mathrm{pH}$ of the leachate changed from its original value to 4 by adding $6 \mathrm{~mol} \mathrm{~L}^{-1} \mathrm{NaOH}$. The system was shaken for 10 min. Phase separation was achieved in $\sim 10 \mathrm{~min}$. The experiments were carried out in triplicate. The distribution ratio, $\mathrm{D}_{\mathrm{M}(\mathrm{II})},(\mathrm{M}=\mathrm{Zn}, \mathrm{Mn})$ is defined as the ratio of metal ion concentration in organic phase to the metal ion concentration in aqueous phase at reaction equilibrium.

Experiments were carried out to assess the influence of $\mathrm{Mn}$ (II) on $\mathrm{Zn}$ (II) extraction by D2EHPA . A $0.3 \mathrm{~mol} \mathrm{~L}^{-1} \mathrm{Mn}$ (II) salt of the anion of the leachant was contacted with 6 vol.\% D2EHPA in n-heptane. The organic phase was then contacted with a $0.3 \mathrm{~mol} \mathrm{~L}^{-1} \mathrm{Zn}$ (II) salt of the same anion. The $\mathrm{pH}$ of the aqueous phases was adjusted to the same value as that of the corresponding leachates by adding the appropriate amount of concentrated acid leachant. The experimental conditions were the same of the extraction process.

The best conditions to remove $\mathrm{Mn}$ (II) and $\mathrm{Zn}$ (II) from the organic phase were also investigated. The organic solutions were contacted with aqueous solutions of acid leachants. The experimental conditions were similar to those of the extraction process.

\section{Precipitation of Mn(II)}

The raffinate was added dropwise to $6 \mathrm{~mol} \mathrm{~L}^{-1} \mathrm{NaOH}$ containing 3 mol L ${ }^{-1} \mathrm{H}_{2} \mathrm{O}_{2}$ under stirring $(200 \mathrm{rpm})$ at $25^{\circ} \mathrm{C}$. Final $\mathrm{pH}$ was set at about 10:

$$
\mathrm{Mn}^{2+}+2 \mathrm{OH}^{-} \rightarrow \mathrm{Mn}(\mathrm{OH})_{2} \downarrow \quad\left(\mathrm{K}_{\mathrm{sp}}=4 \times 10^{-14}\right)
$$

At $\mathrm{pH}$ above 9 this precipitate is readily oxidized by $\mathrm{H}_{2} \mathrm{O}_{2}: 36,37$

$$
\mathrm{Mn}(\mathrm{OH})_{2}+\mathrm{H}_{2} \mathrm{O}_{2} \rightarrow \mathrm{MnO}(\mathrm{OH})_{2} \downarrow+\mathrm{H}_{2} \mathrm{O} \quad\left(\Delta \mathrm{E}^{\mathrm{o}}=+0,60 \mathrm{~V}\right)
$$

The precipitate was filtered and washed with water $\left(5 \mathrm{~mL} \mathrm{~g}^{-1}\right)$, dried at $150{ }^{\circ} \mathrm{C}$ for $3 \mathrm{~h}$ and weighed.

\section{Recovery of sodium salts}

The final solution contains basically $\mathrm{Na}^{+}$and $\mathrm{OH}^{-}$ions and the anion of the leachant $\left(\mathrm{SO}_{4}{ }^{2-}, \mathrm{F}^{-}\right.$or $\left.\mathrm{HCOO}^{-}\right)$. The corresponding acid 
leachant was carefully added to adjust the $\mathrm{pH}$ to the theoretical equilibrium $\mathrm{pH}$ of the saturated solution of the salt $\left(\mathrm{Na}_{2} \mathrm{SO}_{4}-7\right.$; $\mathrm{NaF}-8.5 ; \mathrm{HCOONa}-9.0) .{ }^{36,44}$ The treated solution was then slowly evaporated at $60-70{ }^{\circ} \mathrm{C}$ (without stirring). A white crystalline solid was obtained. The solids were weighed and kept in tightly closed containers.

\section{Analytical methods}

The solids, after milling and drying the active components, the insoluble matter isolated after leaching, the ash isolated after calcining the insoluble matter and the solids obtained during the separation procedure were weighed in an analytical balance (Scientech SA 120) and analyzed by x-ray fluorescence (Shimadzu XRF 800HS). Crystalline phases in the solid samples were identified by X-ray powder diffraction (XRPD, Shimadzu model XRD 6000) by continuous scanning method at $20 \mathrm{~mA}$ and $40 \mathrm{kV}$, using $\mathrm{Cu} \mathrm{K \alpha}$ as the radiation source. Metal ion concentrations in the leachates were determined by atomic absorption spectrometry (Perkin Elmer AAS 3300). $\mathrm{pH}$ measurements were conducted using a combination of a glass electrode and a $\mathrm{Ag} / \mathrm{AgCl}$ reference electrode (Orion 2AI3-JG).

\section{RESULTS AND DISCUSSION}

\section{Composition of the dried electroactive components}

Table 1 presents the average composition of the solid after milling and drying the active components of spent zinc- $\mathrm{MnO}_{2}$ dry cells. It must be emphasized that lead has been found in detectable amounts only in Brazilian Leclanché cells. ${ }^{13,22,45}$

\section{Leaching results}

The reproducibility of leaching was determined to be about \pm $4 \%$. Manganese and zinc were leached with high yields (> $95 \mathrm{wt} . \%$, Table 2) after $1 \mathrm{~h}(\mathrm{HF})$ or $3 \mathrm{~h}\left(\mathrm{HCOOH}\right.$ and $\left.\mathrm{H}_{2} \mathrm{SO}_{4}\right)$. These results are comparable to the best ones reported in the literature ${ }^{20}$ using strong acids. Leaching with $\mathrm{H}_{2} \mathrm{SO}_{4}$ was somewhat longer than the average time reported in the literature,,$^{5,714,16}$ but temperature was higher in such studies $\left(40-90^{\circ} \mathrm{C}\right)$ than in the present work and carbon was not eliminated.

Iron and aluminum were especially leached by HF probably due to formation of complexes ${ }^{36,44}$ such as $\left[\mathrm{AlF}_{6}\right]^{3-}$ and $\left[\mathrm{FeF}_{6}\right]^{3-}$. Calcium, barium and lead were not found in $\mathrm{HF}$ and $\mathrm{H}_{2} \mathrm{SO}_{4}$ leachates because their fluorides/sulfates are insoluble or very sparingly soluble in water. ${ }^{36,37,44}$ Soluble silicon (as $\left[\mathrm{SiF}_{6}\right]^{2-}$ ions) was found when $\mathrm{HF}+\mathrm{H}_{2} \mathrm{O}_{2}$ was the leachant. ${ }^{36,37,44}$
Table 1. Average composition of the electroactive components of zinc- $\mathrm{MnO}_{2}$ dry cells after drying $\left(40^{\circ} \mathrm{C}, 24 \mathrm{~h}\right)$

\begin{tabular}{cc}
\hline Element $^{*}$ & wt.\% \\
\hline $\mathrm{Mn}$ & 29.0 \\
$\mathrm{Zn}$ & 23.0 \\
$\mathrm{Si}$ & 0.4 \\
$\mathrm{Fe}$ & 0.1 \\
$\mathrm{~K}$ & 2.4 \\
$\mathrm{Na}$ & 0.6 \\
$\mathrm{~Pb}$ & $2.0 \times 10^{-3}$ \\
$\mathrm{Ca}$ & $6.9 \times 10^{-2}$ \\
$\mathrm{Ba}$ & $1.1 \times 10^{-2}$ \\
$\mathrm{Al}$ & $6.0 \times 10^{-2}$ \\
$\mathrm{Ni}$ & $3.0 \times 10^{-3}$ \\
$\mathrm{Cu}$ & $2.9 \times 10^{-3}$ \\
$\mathrm{Cr}$ & $6.0 \times 10^{-2}$ \\
$\mathrm{Ti}$ & $1.1 \times 10^{-2}$ \\
$\mathrm{C}$ & 9.0 \\
\hline
\end{tabular}

* $\mathrm{Hg}$ and $\mathrm{Cd}$ are present in amounts below $10 \mu \mathrm{g} \mathrm{kg}^{-1}$ in Brazilian zinc-MnO dry cells. ${ }^{13,45}$

Table 3 presents the concentration of leached species after adding the washing waters. All solutions were pale pink, which is typical of $\mathrm{Mn}^{2+}{ }_{\text {aq. }}{ }^{36,44}$ Iron and aluminum were present in very low amounts. Other elements found $\left(<0.1 \mathrm{mg} \mathrm{L}^{-1}\right)$ were nickel, silicon, copper and chromium. The concentrations shown in Table 3 vary according to the amount of water used to wash the insoluble matter $\left(\mathrm{H}_{2} \mathrm{SO}_{4}, 80 \mathrm{~mL} \mathrm{~g}^{-1}\right.$ dried electroactive components; $\mathrm{HF}, 25 \mathrm{~mL} \mathrm{~g}^{-1}$; $\left.\mathrm{HCOOH}, 20 \mathrm{~mL} \mathrm{~g}^{-1}\right)$. The average $\mathrm{pH}$ was $0.9\left(\mathrm{H}_{2} \mathrm{SO}_{4}\right)$ and $1.1(\mathrm{HF}$ and $\mathrm{HCOOH}) . \mathrm{Mn}^{2+}$ ions are the stable aqueous species over a broad redox potential $\left(\mathrm{E}_{\mathrm{h}}\right)$ range. ${ }^{33,34}$

\section{Analysis of the insoluble matter after leaching}

The amount of insoluble matter (Table 4) increased following $\mathrm{HF}<\mathrm{H}_{2} \mathrm{SO}_{4}<\mathrm{HCOOH}$. After calcination, the mass loss was essentially the same $(\sim 8.5 \mathrm{wt} . \%)$, in agreement with the carbon content ( $\sim$ wt. \%, Table 1), except for formic acid, where mass loss was much higher. The $\mathrm{pH}$ of the aqueous solution of the gaseous effluent produced during calcination was always acid and increased accordingly: $\mathrm{HCOOH}(5.8)<\mathrm{H}_{2} \mathrm{SO}_{4}(6.2) \approx \mathrm{HF}(6.3)$. After adding acetic acid (elimination of $\left.\mathrm{CO}_{2}\right)$ no precipitate or turbidity $\left(\mathrm{CaF}_{2}\right.$ or $\left.\mathrm{BaSO}_{4}\right)$ was found after adding $\mathrm{Ca}\left(\mathrm{NO}_{3}\right)_{2}$ or $\mathrm{Ba}\left(\mathrm{NO}_{3}\right)_{2}$ to the corresponding solutions from the experiments with $\mathrm{HF}$ and $\mathrm{H}_{2} \mathrm{SO}_{4}$. The acidity came mainly from $\mathrm{CO}_{2 \text { (aq.) }}$. The lowest $\mathrm{pH}$ value found

Table 2. Leached elements* after 1-3 h

\begin{tabular}{|c|c|c|c|c|c|c|c|}
\hline Leachant & $\begin{array}{l}\text { Time } \\
\text { (h) }\end{array}$ & $\begin{array}{c}\mathrm{Zn} \\
\text { (wt.\%) }\end{array}$ & $\begin{array}{c}\mathrm{Mn} \\
\text { (wt.\%) }\end{array}$ & $\begin{array}{c}\mathrm{Si} \\
\text { (wt.\%) }\end{array}$ & $\begin{array}{c}\mathrm{Pb} \\
\text { (wt.\%) }\end{array}$ & $\begin{array}{c}\mathrm{Fe} \\
\text { (wt.\%) }\end{array}$ & $\begin{array}{c}\mathrm{Al} \\
\text { (wt.\%) }\end{array}$ \\
\hline \multirow{3}{*}{$\mathrm{H}_{2} \mathrm{SO}_{4}+\mathrm{H}_{2} \mathrm{O}_{2}$} & 1 & 99.5 & 90.4 & Negligible & Negligible & 26.0 & 74.1 \\
\hline & 2 & 99.8 & 96.3 & Negligible & Negligible & 34.1 & 77.1 \\
\hline & 3 & $>99.9$ & 97.3 & Negligible & Negligible & 35.9 & 78.0 \\
\hline \multirow{3}{*}{$\mathrm{HF}+\mathrm{H}_{2} \mathrm{O}_{2}$} & 1 & $>99.9$ & 99.2 & 99.9 & $<0.1$ & 97.0 & 99.8 \\
\hline & 2 & 99.8 & 98.0 & 97.4 & Negligible & 99.0 & 99.6 \\
\hline & 3 & 99.1 & 97.6 & 95.9 & Negligible & 99.5 & 99.1 \\
\hline \multirow{2}{*}{$\mathrm{HCOOH}+\mathrm{H}_{2} \mathrm{O}$} & 2 & 93.0 & 89.0 & Negligible & 85 & 30.1 & 85.0 \\
\hline & 3 & 99.9 & 97.1 & Negligible & 90 & 31.9 & 88.9 \\
\hline
\end{tabular}

*After adding the washings to the leachate. 
Table 3. Typical metal ion concentrations* after leaching for $3 \mathrm{~h}$

\begin{tabular}{lcccccc}
\hline Leachant & $\begin{array}{c}\mathrm{Mn}(\mathrm{II}) \\
\left(\mathrm{g} \mathrm{L}^{-1}\right)\end{array}$ & $\begin{array}{c}\mathrm{Zn}(\mathrm{II}) \\
\left(\mathrm{g} \mathrm{L}^{-1}\right)\end{array}$ & $\begin{array}{c}\mathrm{Fe}(\mathrm{III}) \\
\left(\mathrm{mg} \mathrm{L}^{-1}\right)\end{array}$ & $\begin{array}{c}\mathrm{Al}(\mathrm{III}) \\
\left(\mathrm{mg} \mathrm{L}^{-1}\right)\end{array}$ & $\begin{array}{c}\mathrm{Pb}(\mathrm{II}) \\
\left(\mathrm{mg} \mathrm{L}^{-1}\right)\end{array}$ & $\begin{array}{c}\mathrm{Ba}(\mathrm{II})+\mathrm{Ca}(\mathrm{II}) \\
\left(\mathrm{mg} \mathrm{L}^{-1}\right)\end{array}$ \\
\hline $\mathrm{H}_{2} \mathrm{SO}_{4}+\mathrm{H}_{2} \mathrm{O}_{2}$ & 5.5 & 4.5 & 4.0 & 5.1 & Negligible & $<0.1$ \\
$\mathrm{HF}+\mathrm{H}_{2} \mathrm{O}_{2}$ & 8.9 & 7.6 & 29.8 & 17.0 & Negligible & Negligible \\
$\mathrm{HCOOH}+\mathrm{H}_{2} \mathrm{O}$ & 13.6 & 11.5 & 10.1 & 17.9 & 0.6 & 25.1 \\
\hline
\end{tabular}

*After adding the washings to the leachate.

for $\mathrm{HCOOH}$ suggests an additional source of $\mathrm{CO}_{2}$ : the leachant itself. This point requires further investigation, but it is likely that some acid (and/or the formate anion) was strongly adsorbed on carbon; the acid is easily thermally decomposed under oxidant atmosphere: ${ }^{36}$

$2 \mathrm{HCOOH}+\mathrm{O}_{2} \rightarrow 2 \mathrm{CO}_{2}+2 \mathrm{H}_{2} \mathrm{O} \quad\left(\Delta \mathrm{E}^{\mathrm{o}}=+1,83 \mathrm{~V}\right)$

Table 4. Mass of insoluble matter after leaching before and after calcining $\left(600{ }^{\circ} \mathrm{C}, 3 \mathrm{~h}\right.$ ) (Base: $1 \mathrm{~g}$ of dried original mass)

\begin{tabular}{lcccc}
\hline Leachant & Time (h) & $\begin{array}{c}\text { Before } \\
\text { calcining (mg) calcining (mg) }\end{array}$ & $\begin{array}{c}\text { After } \\
(\mathrm{mg})\end{array}$ \\
\hline & 1 & 142 & 56 & 86 \\
$\mathrm{H}_{2} \mathrm{SO}_{4}+\mathrm{H}_{2} \mathrm{O}_{2}$ & 2 & 147 & 53 & 94 \\
& 3 & 109 & 25 & 84 \\
\hline $\mathrm{HF}+\mathrm{H}_{2} \mathrm{O}_{2}$ & 1 & 92 & 12 & 80 \\
& 2 & 106 & 18 & 88 \\
& 3 & 103 & 19 & 84 \\
$\mathrm{HCOOH}+\mathrm{H}_{2} \mathrm{O}$ & 2 & 235 & 87 & 148 \\
& 3 & 139 & 24 & 115 \\
\hline
\end{tabular}

The chemical composition of the insoluble matter after calcination is presented in Table 5. Manganese is the most abundant element. The high amounts of alkali-earth metals in the insoluble matter after experiments with $\mathrm{HF}$ and $\mathrm{H}_{2} \mathrm{SO}_{4}$ and the low amount of silicon in the experiments with $\mathrm{HF}$ correlate with the insolubility of $\mathrm{CaF}_{2} /$ $\mathrm{BaF}_{2}$ and $\mathrm{CaSO}_{4} / \mathrm{BaSO}_{4}$ in water and the presence of $\mathrm{SiF}_{6}{ }^{2-}$ ions in the leachate, respectively.

The diffractograms of the insoluble matter show the presence of manganese oxides: $\mathrm{Mn}_{3} \mathrm{O}_{4}$ and $\mathrm{Mn}_{2} \mathrm{O}_{3}(\mathrm{HCOOH}$, Figure $1 \mathrm{~A}) ; \mathrm{Mn}_{3} \mathrm{O}_{4}$ (HF, Figure 1B); $\mathrm{Mn}_{2} \mathrm{O}_{3}\left(\mathrm{H}_{2} \mathrm{SO}_{4}\right.$, Figure 1C). $\mathrm{Mn}_{3} \mathrm{O}_{4}$ is the expected phase when manganese oxides are heated in air at about $500{ }^{\circ} \mathrm{C},{ }^{46}$ but tends to be slowly oxidized to $\mathrm{Mn}_{2} \mathrm{O}_{3}$ above $560{ }^{\circ} \mathrm{C} .{ }^{24}$
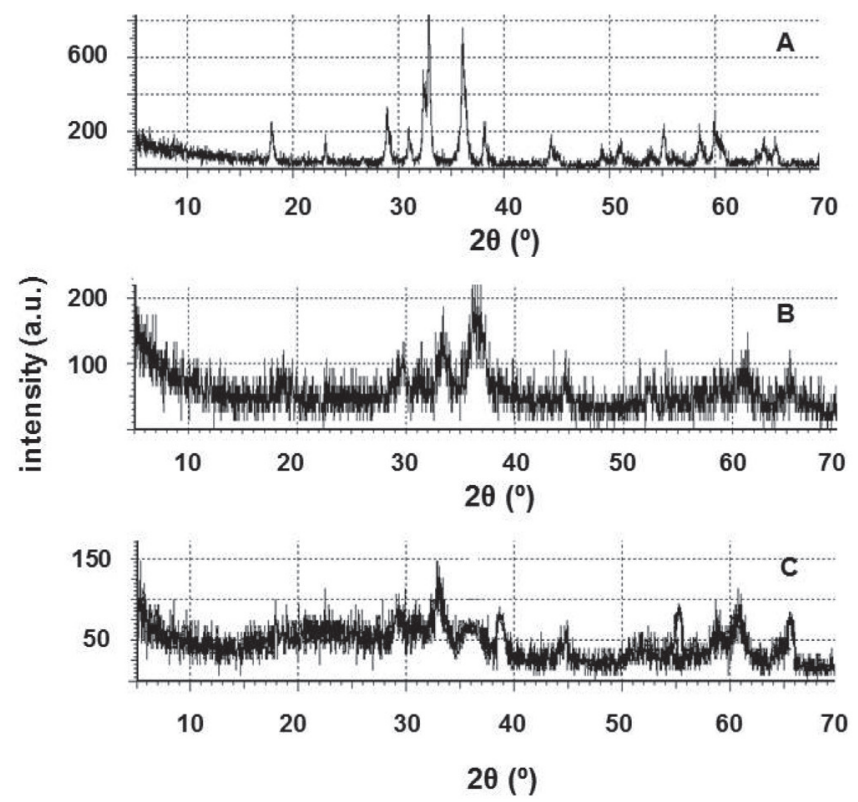

Figure 1. XRPD patterns of the insoluble residue in water after leaching with $\mathrm{HCOOH}+\mathrm{H}_{2} \mathrm{O}(\mathrm{A}), \mathrm{HF}+\mathrm{H}_{2} \mathrm{O}_{2}(\mathrm{~B})$ and $\mathrm{H}_{2} \mathrm{SO}_{4}+\mathrm{H}_{2} \mathrm{O}_{2}(\mathrm{C})$ followed by calcination at $600^{\circ} \mathrm{C}$ for $3 \mathrm{~h}$

\section{SX of $\mathrm{Zn}(\mathbf{I I})$}

Influence of extractant concentration on $\mathrm{Zn}(\mathrm{II})$ extraction

In these experiments, the $\mathrm{pH}$ of the leachate was not modified. The reproducibility was determined to be within $\pm 5 \%$. $\mathrm{Zn}$ (II) extraction increased with the increase of the extractant concentration regardless of the leachant (Figure 2). This result is in agreement with literature data for D2EHPA. . $5,27,28,31,42^{2}$

The graph $\log$ D as a function of $\log$ [D2EHPA] (Figure 3 ) shows that the slope is close to 2 for all leachants. The extraction reaction is well established in sulfuric medium:

$\mathrm{Zn}^{2+}{ }_{\text {(aq.) }}+(\mathrm{HD})_{2 \text { (org.) }} \rightleftarrows \mathrm{Zn}(\mathrm{D})_{2 \text { (org.) }}+2 \mathrm{H}^{+}{ }_{\text {(aq.) }}(\mathrm{HD}=\mathrm{D} 2 \mathrm{EHPA})(16)$

Table 5. Main components of the insoluble matter after calcination at $600{ }^{\circ} \mathrm{C}$ for $3 \mathrm{~h}$

\begin{tabular}{|c|c|c|c|c|c|c|c|c|}
\hline Leachant & & $\begin{array}{c}\mathrm{ZnO} \\
\text { (wt.\%) }\end{array}$ & $\begin{array}{l}\mathrm{MnO} \\
\text { (wt.\%) }\end{array}$ & $\begin{array}{c}\mathrm{SiO}_{2} \\
\text { (wt.\%) }\end{array}$ & $\begin{array}{c}\mathrm{PbO} \\
\text { (wt.\%) }\end{array}$ & $\begin{array}{l}\mathrm{Fe}_{2} \mathrm{O}_{3} \\
\text { (wt.\%) }\end{array}$ & $\begin{array}{l}\mathrm{Al}_{2} \mathrm{O}_{3} \\
\text { (wt.\%) }\end{array}$ & $\begin{array}{c}\mathrm{BaO}+\mathrm{CaO} \\
(\text { wt. } \%)\end{array}$ \\
\hline \multirow{3}{*}{$\mathrm{H}_{2} \mathrm{SO}_{4}+\mathrm{H}_{2} \mathrm{O}_{2}$} & $(1 \mathrm{~h})$ & 1.7 & 69.9 & 22.6 & 0.2 & 0.8 & 1.9 & 2.6 \\
\hline & $(2 \mathrm{~h})$ & 1.6 & 49.6 & 45.8 & 0.1 & 0.6 & 0.6 & 1.6 \\
\hline & $(3 \mathrm{~h})$ & 1.4 & 48.6 & 44.9 & 0.1 & 0.6 & 0.4 & 3.8 \\
\hline \multirow{3}{*}{$\mathrm{HF}+\mathrm{H}_{2} \mathrm{O}_{2}$} & $(1 \mathrm{~h})$ & 2.1 & 87.5 & 1.8 & 0.2 & 0.5 & 0.3 & 7.5 \\
\hline & $(2 \mathrm{~h})$ & 3.4 & 85.1 & 3.7 & 0.2 & 0.2 & 0.3 & 7.0 \\
\hline & $(3 \mathrm{~h})$ & 3.5 & 85.8 & 3.7 & 0.2 & $<0.1$ & 0.4 & 6.3 \\
\hline \multirow{2}{*}{$\mathrm{HCOOH}+\mathrm{H}_{2} \mathrm{O}$} & $(2 \mathrm{~h})$ & 2.1 & 57.5 & 35.6 & 0.4 & 1.7 & 1.4 & 1.0 \\
\hline & $(3 \mathrm{~h})$ & 1.4 & 50.7 & 44.9 & 0.1 & 1.3 & 0.7 & 0.4 \\
\hline
\end{tabular}


Therefore, this reaction is also valid for $\mathrm{HF}$ and $\mathrm{HCOOH}$. A net effect of Eq. 16 is the increase of the acidity of the raffinate. Experimental data confirm that the raffinate is more acidic than the original leachate: $0.74\left(\mathrm{H}_{2} \mathrm{SO}_{4}\right), 0.92(\mathrm{HF})$ and $0.95(\mathrm{HCOOH})$

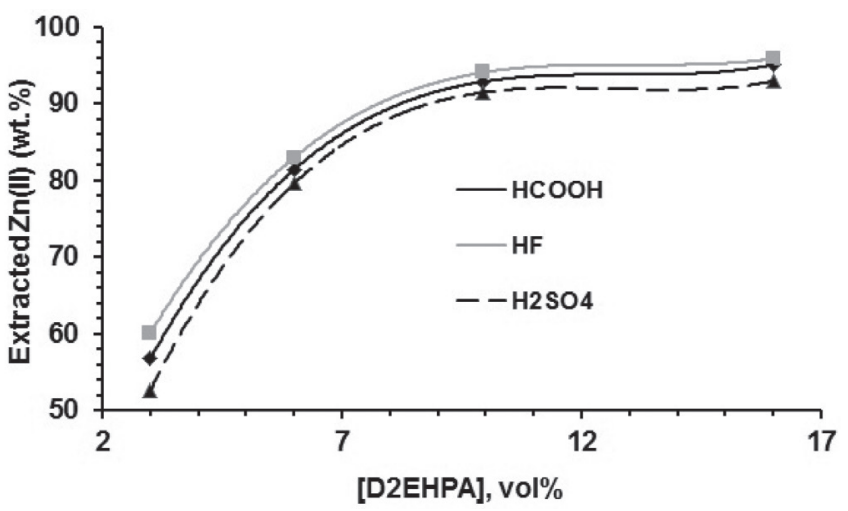

Figure 2. Influence of D2EHPA concentration on $\mathrm{Zn}(\mathrm{II})$ extraction in the $\mathrm{pH}$ of the leachates (one stage, $A / O=1 \mathrm{v} / \mathrm{v}, 25^{\circ} \mathrm{C}$ )

$\mathrm{Zn}$ (II) was best extracted with D2EHPA from the leachates of the weak acids: $\mathrm{HF}>\mathrm{HCOOH}>\mathrm{H}_{2} \mathrm{SO}_{4}$ (Figure 3). Release of acidity (Eq. 16) to the aqueous phase tends to reduce the extraction rate, but the $\mathrm{H}_{3} \mathrm{O}^{+}$ions can restore the original weak acid: ${ }^{36,37}$

$\mathrm{H}_{3} \mathrm{O}^{+}+\mathrm{X}^{-} \rightleftarrows \mathrm{HX}+\mathrm{H}_{2} \mathrm{O}\left(\mathrm{X}=\mathrm{F}^{-}, \mathrm{HCOO}^{-}\right)$

$\left(\mathrm{K}=1.48 \times 10^{3}\right.$ for $\mathrm{HF}$ and $2.65 \times 10^{3}$ for $\left.\mathrm{HCOOH}^{36}\right)$

thus removing some of the acidity released by Eq. 16. In general, $\mathrm{Zn}$ (II) extraction with D2EHPA at $\mathrm{pH} 1$ is not so effective. Typical $\mathrm{pH}_{0.5}$ values (equilibrium $\mathrm{pH}$ at which $50 \%$ metal extraction occurs) for $\mathrm{Zn}(\mathrm{II})$ are between $0.8-1.3 .^{25,27,30,31}$ Furthermore, $\mathrm{Zn}$ (II) concentration (Table 3) was lower than in most literature studies (usually above $10 \mathrm{~g} \mathrm{~L}^{-1}$ ).

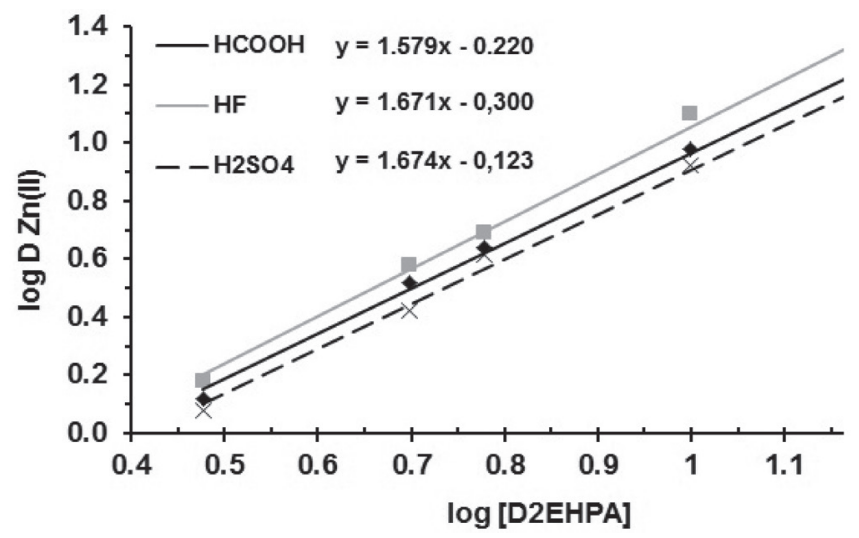

Figure 3. Graph of $\log D$ as a function of $\log$ [D2EHPA] for Zn(II) extraction in the $\mathrm{pH}$ of the leachates (one stage, $\mathrm{A} / \mathrm{O}=1 \mathrm{v} / \mathrm{v}, 25^{\circ} \mathrm{C}$ )

\section{Mn(II) extraction}

The increase of extractant concentration also increased Mn(II) extraction (Figure 4). In contrast to $\mathrm{Zn}$ (II), Mn(II) was especially extracted from the sulfuric leachates, but was hardly extracted in the presence of $\mathrm{HF}$.

A greater amount of $\mathrm{Mn}(\mathrm{II})$ was extracted from its $0.3 \mathrm{~mol} \mathrm{~L}^{-1}$ salts (Table 6) than from the corresponding leachates (Figure 5), but the extraction followed the same trend: $\mathrm{H}_{2} \mathrm{SO}_{4}>\mathrm{HCOOH}>\mathrm{HF}$. From data in Table 6, more than 90 wt.\% of Mn(II) in the organic phase was displaced by $0.3 \mathrm{~mol} \mathrm{~L}^{-1}$ aqueous $\mathrm{Zn}$ (II) in all experiments.

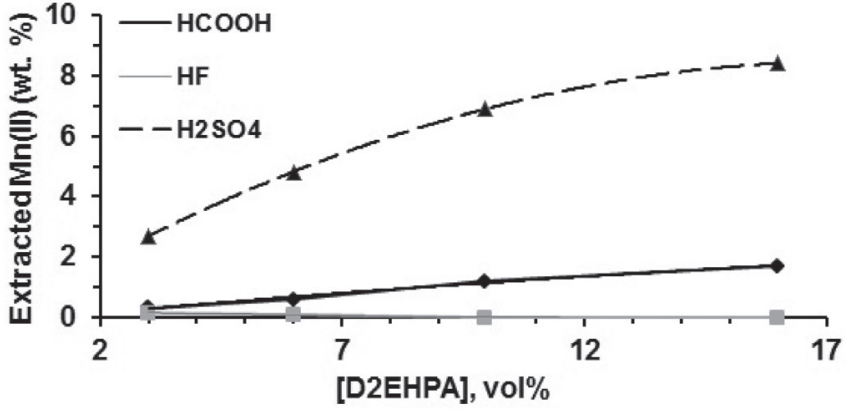

Figure 4. Effect of D2EHPA concentration on Mn(II) extraction in the pH of the leachates (one stage, $A / O=1 \mathrm{v} / \mathrm{v}, 25^{\circ} \mathrm{C}$ )

Table 6. Extraction of $0.3 \mathrm{~mol} \mathrm{~L}^{-1} \mathrm{Mn}$ (II) by 6 vol.\% D2EHPA followed by extraction of $0.3 \mathrm{~mol} \mathrm{~L}^{-1} \mathrm{Zn}$ (II) by 6 vol. $\%$ D2EHPA containing Mn(II) (one stage, $\left.\mathrm{A} / \mathrm{O}=1 \mathrm{v} / \mathrm{v}, 25^{\circ} \mathrm{C}\right)$

\begin{tabular}{lcc}
\hline Manganese salt & $\begin{array}{c}\text { wt.\% extracted by } \\
\text { D2EHPA }\end{array}$ & $\begin{array}{c}\text { wt.\% removed by } \\
0.3 \mathrm{~mol} \mathrm{~L}^{-1} \mathrm{Zn}(\mathrm{II})\end{array}$ \\
\hline $\mathrm{MnSO}_{4}$ & 10 & $91\left(\mathrm{ZnSO}_{4}\right)$ \\
$\mathrm{MnF}_{2}$ & 2 & $99\left(\mathrm{ZnF}_{2}\right)$ \\
$\mathrm{Mn}(\mathrm{HCOO})_{2}$ & 6 & $95\left(\mathrm{Zn}(\mathrm{HCOO})_{2}\right)$ \\
\hline
\end{tabular}

These results confirm a preferential extraction of $\mathrm{Zn}$ (II) over Mn(II) by D2EHPA under our experimental conditions.

\section{Influence of leachate $\mathrm{pH}$ on $\mathrm{Zn}(\mathrm{II})$ and $\mathrm{Mn}(\mathrm{II})$ extraction}

D2EHPA concentration was fixed at 6 vol.\%. Zn(II) extraction increased as the $\mathrm{pH}$ of the leachants increased (Figure 5) regardless of the leachant. This is the normal behavior found in sulfuric medium. ${ }^{25,27,30,31}$ More than 95 wt.\% of $\mathrm{Zn}$ (II) was extracted in one stage at pH 2 ( $\mathrm{HF}$ and $\mathrm{HCOOH})$ and $2.5\left(\mathrm{H}_{2} \mathrm{SO}_{4}\right)$. More $\mathrm{Mn}(\mathrm{II})$ was extracted as $\mathrm{pH}$ increased $\left(\mathrm{H}_{2} \mathrm{SO}_{4}>\mathrm{HCOOH}>\mathrm{HF}\right)$, also in agreement with literature data. ${ }^{2}$

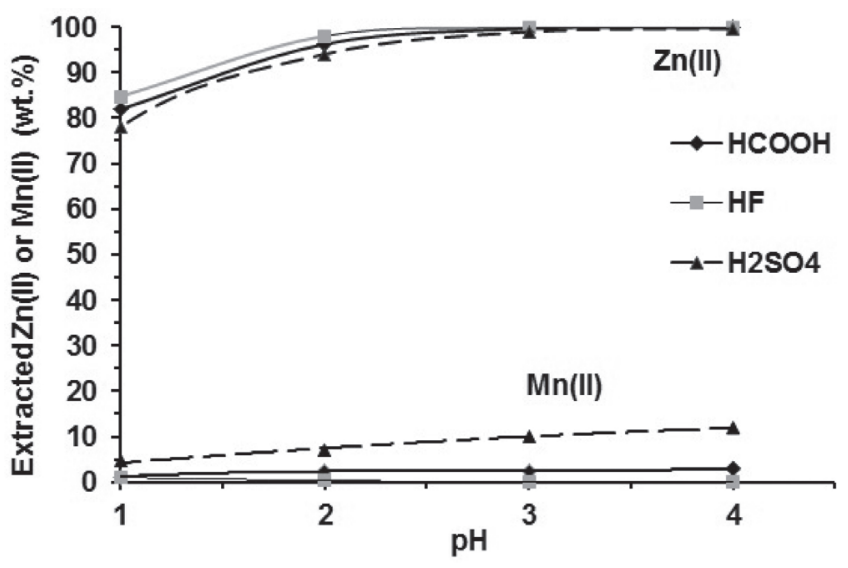

Figure 5. Influence of acidity on $\mathrm{Zn}(\mathrm{II})$ and $\mathrm{Mn}(\mathrm{II})$ extraction with 6 vol.\% D2EHPA (one stage, $A / O=1 \mathrm{v} / \mathrm{v}, 25^{\circ} \mathrm{C}$ )

\section{Removal of $\mathrm{Mn}(I I)$ and $\mathrm{Zn}(I I)$ from the organic phase}

$\mathrm{Mn}(\mathrm{II})$ was easily scrubbed (> $99.5 \mathrm{wt} . \%$ ) in one stage using a dilute leachant (1-2 mol L-1, Figure 6). A similar result has already been reported in the literature. ${ }^{26} \mathrm{Zn}$ (II) was not removed. The aqueous solution was added to the raffinate.

In contrast to $\mathrm{Mn}(\mathrm{II})$, the weak acids were not able to remove $\mathrm{Zn}$ (II) from the organic phase irrespective to their concentration. $2 \mathrm{~mol} \mathrm{~L}^{-1} \mathrm{H}_{2} \mathrm{SO}_{4}$ began to strip it. ${ }^{2,26,27,31}$ More than 99.5 wt.\% was 
stripped in one stage using $5 \mathrm{~mol} \mathrm{~L}^{-1} \cdot \mathrm{H}_{2} \mathrm{SO}_{4}$ concentration should not surpass $8 \mathrm{~mol} \mathrm{~L}^{-1}$ to avoid emulsification. Manganese was not detected in the aqueous solution.
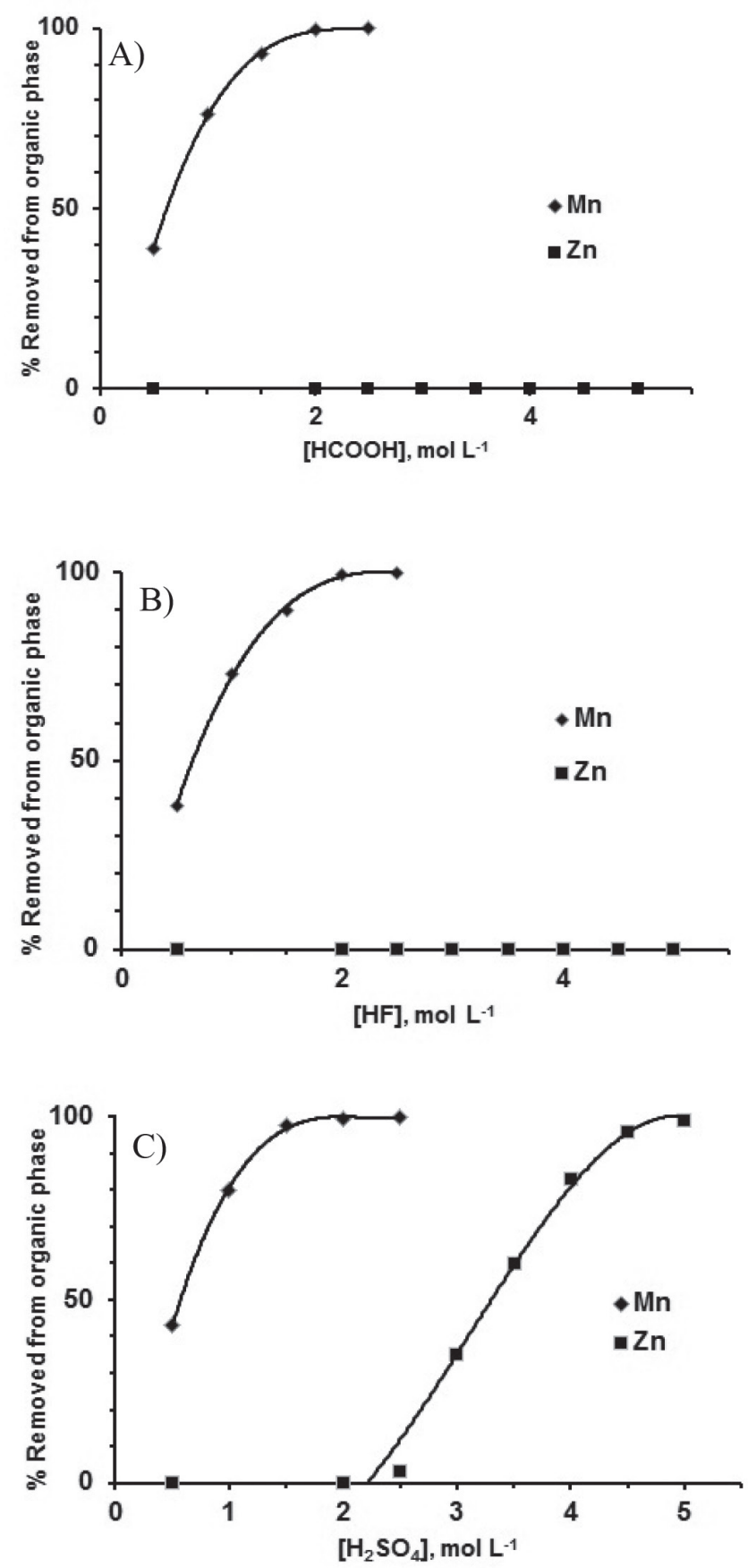

Figure 6. Removal of $\mathrm{Zn}(I I)$ and $M n(I I)$ from the organic phase with aqueous leachants at variable concentrations (one stage, $A / O=1$ vol. $/$ vol., $25^{\circ} \mathrm{C}$ )

\section{Mn(II) precipitation}

Manganese dioxide comprises over $98.5 \mathrm{wt} \%$ of the solid precipitated at $\mathrm{pH} \sim 9$. The impurities come from the remaining $\mathrm{Zn}(\mathrm{II})$ (0.2-0.5 wt.\%), the other leached elements (Fe, $\mathrm{Al}-0.4-0.5$ wt.\%) and, occasionally, $\mathrm{Pb}, \mathrm{Ca}, \mathrm{Ba}$ and $\mathrm{Si}$ (0.3 wt.\% maximum). $\mathrm{Zn}$ (II), Al(III) and $\mathrm{Pb}(\mathrm{II})$ form complexes with hydroxide ions at high $\mathrm{pH} .{ }^{36,37,44} \mathrm{At}$ $\mathrm{pH} \sim 9$ such reactions were avoided, which led to the precipitation of these elements with manganese. Its diffractogram shows that the solid containing manganese is amorphous.

\section{Recovery of the sodium salt of the anion of the leachant}

The diffractograms shown in Figure 7 contain peaks corresponding to a single anhydrous salt. XRF data show the absence of zinc, manganese and other metals found in the leachates (they were precipitated with manganese). This is of special importance for the recovery of high value-added salts ( $\mathrm{NaF}$ and $\mathrm{HCOONa})$. After drying the solids at $150{ }^{\circ} \mathrm{C}$ for $3 \mathrm{~h}$, the mass loss was lower than $3 \mathrm{wt} . \%$, thus confirming that all salts were anhydrous.
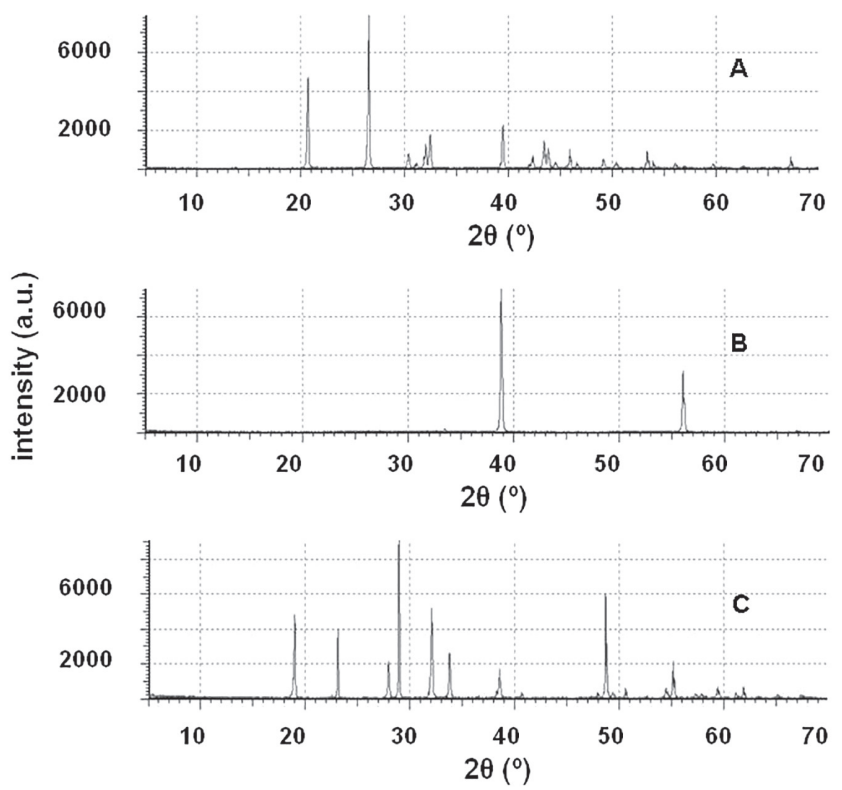

Figure 7. XRPD patterns of the solids recovered after slow evaporation of the final solution. The peaks represent $\mathrm{HCOONa}(\mathrm{A}), \mathrm{NaF}(\mathrm{B})$ and $\mathrm{Na}_{2} \mathrm{SO}_{4}(\mathrm{C})$

Table 7. Average recovery of the sodium salts of the anions of the leachants (base: $1 \mathrm{~kg}$ of electroactive components)

\begin{tabular}{ccccc}
\hline Acid leachant & Salt & $\begin{array}{c}\text { Expected } \\
\text { mass }(\mathrm{kg})^{*}\end{array}$ & $\begin{array}{c}\text { Recovered } \\
\text { mass }(\mathrm{kg})\end{array}$ & $\%$ \\
\hline $\mathrm{H}_{2} \mathrm{SO}_{4}$ & $\mathrm{Na}_{2} \mathrm{SO}_{4}$ & 31.50 & 31.27 & 99.3 \\
$\mathrm{HF}$ & $\mathrm{NaF}$ & 5.25 & 5.10 & 97.1 \\
$\mathrm{HCOOH}$ & $\mathrm{HCOONa}$ & 8.54 & 7.70 & 90.1 \\
\hline
\end{tabular}

* $\mathrm{Na}_{2} \mathrm{SO}_{4}$ : four sources: leaching, $\mathrm{Mn}$ (II) scrubbing, $\mathrm{Zn}(\mathrm{II})$ stripping and salt crystallization. $\mathrm{HF}$ and $\mathrm{HCOOH}$ : three sources: leaching, Mn(II) scrubbing and salt crystallization.

\section{Rough economic analysis}

No detailed study on economics was performed, but some insight can be obtained based on the market value of the reactants, energy, water and products. The present average prices (for the same purity grade) in Brazil for bulk quantities are:47 $49 \mathrm{wt} . \%\left(9 \mathrm{~mol} \mathrm{~L}^{-1}\right)$ $\mathrm{H}_{2} \mathrm{SO}_{4}$, US\$ $10 \mathrm{~L}^{-1} ; 40$ wt. $\%\left(20 \mathrm{~mol} \mathrm{~L}^{-1}\right) \mathrm{HF}$, US\$ $90 \mathrm{~L}^{-1} ; 88$ wt. $\%$ (20 mol L-1) HCOOH, US\$ $120 \mathrm{~L}^{-1}$; 30 wt.\% ( 10 mol L-1) $\mathrm{H}_{2} \mathrm{O}_{2}$, US\$ $350 \mathrm{~L}^{-1}$; D2EHPA, US\$ $500 \mathrm{~L}^{-1}$; n-heptane, US\$ $103 \mathrm{~L}^{-1}$; $6 \mathrm{~mol} \mathrm{~L}-1 \mathrm{NaOH}$, US\$ $50 \mathrm{~L}^{-1}$; water, US\$ $5 \mathrm{~m}^{-3}$ (including taxes); energy, US\$ $0.30 \mathrm{kWh}^{-1}$ (including taxes); $\mathrm{Na}_{2} \mathrm{SO}_{4}$ (> 99.5 wt.\%), US\$ $160 \mathrm{~kg}^{-1}$; NaF (> 99.5 wt.\%), US\$ $500 \mathrm{~kg}^{-1}$; HCOONa (> 99.5 wt.\%), US\$ $650 \mathrm{~kg}^{-1}$; ZnO (99.5 wt.\%), US\$ $100 \mathrm{~kg}^{-1}$; $\mathrm{MnO}_{2}$ (technical grade, 95-98 wt.\%), US\$ $125 \mathrm{~kg}^{-1}$. Carbon was not included in this study because of its very low price ( $\left.\sim \mathrm{US} \$ 0.10 \mathrm{~kg}^{-1}\right)$ and the low amount recovered (84-148 $\mathrm{g} \mathrm{kg}^{-1}$ active components, 
Table 8. Rough economic analysis of the processes described in this work (Base: $1 \mathrm{~kg}$ of active components of spent zinc-MnO $\mathrm{M}_{2}$ dry cells)

\begin{tabular}{|c|c|c|c|}
\hline Item & $\mathrm{H}_{2} \mathrm{SO}_{4}$ & $\mathrm{HF}$ & $\mathrm{HCOOH}$ \\
\hline Acid & $5 \mathrm{~L}(\mathrm{US} \$ 50)$ & $5 \mathrm{~L}(\mathrm{US} \$ 450)$ & $5 \mathrm{~L}(\mathrm{US} \$ 600)$ \\
\hline $\mathrm{H}_{2} \mathrm{O}_{2}$ or $\mathrm{H}_{2} \mathrm{O}$ & $5 \mathrm{~L}(\mathrm{US} \$ 1750)$ & $5 \mathrm{~L}(\mathrm{US} \$ 1750)$ & $5 \mathrm{~L}(\mathrm{US} \$ 0.03)$ \\
\hline Energy consumption ${ }^{* 1}$ & $10 \mathrm{kWh}^{-1}$ (US\$ 3$)$ & $10 \mathrm{kWh}^{-1}(\mathrm{US} \$ 3)$ & $22 \mathrm{kWh}^{-1}(\mathrm{US} \$ 6.60)$ \\
\hline Washing insoluble matter & $8.8 \mathrm{~L}$ (US\$ 0.044) & $2.5 \mathrm{~L}(\mathrm{US} \$ 0.018)$ & 2.8 L (US\$ 0.014) \\
\hline n-heptane & 17.67 L (US\$ 606.74) & 11.75 L (US\$ 403.42) & $12.03 \mathrm{~L}(\mathrm{US} \$ 413.10)$ \\
\hline D2EHPA & $1.13 \mathrm{~L}(\mathrm{US} \$ 564)$ & $0.75 \mathrm{~L}$ (US\$ 375) & 0.77 L (US\$ 384) \\
\hline $6 \mathrm{~mol} \mathrm{~L}^{-1} \mathrm{NaOH}^{* 2}$ & $0.4 \mathrm{~L}(\mathrm{US} \$ 20)$ & 0.18 L (US\$ 9) & $0.18 \mathrm{~L}(\mathrm{US} \$ 9)$ \\
\hline Mn(II) scrubbing*3 & 18.8 L (US\$ 20.40) & $12.5 \mathrm{~L}(\mathrm{US} \$ 112.56)$ & $12.8 \mathrm{~L}(\mathrm{US} \$ 153.66)$ \\
\hline Zn(II) stripping ${ }^{* 4}$ & $18.8 \mathrm{~L}$ (US\$ 78.37) & $12.5 \mathrm{~L}(\mathrm{US} \$ 52.10)$ & $12.8 \mathrm{~L}$ (US\$ 53.50) \\
\hline $6 \mathrm{~mol} \mathrm{~L}^{-1} \mathrm{NaOH}^{* 5}$ & $15.7 \mathrm{~L}(\mathrm{US} \$ 785)$ & 10.5 L (US\$ 525) & 10.7 L (US\$ 535) \\
\hline $6 \mathrm{~mol} \mathrm{~L}^{-1} \mathrm{NaOH}^{* 6}$ & 25.2 L (US\$ 1260) & $4.5 \mathrm{~L}(\mathrm{US} \$ 225)$ & $4.5 \mathrm{~L}$ (US\$225) \\
\hline $30 \mathrm{wt} \% \mathrm{H}_{2} \mathrm{O}_{2}{ }^{* 7}$ & $0.5 \mathrm{~L}(\mathrm{US} \$ 175)$ & $0.5 \mathrm{~L}(\mathrm{US} \$ 175)$ & $0.5 \mathrm{~L}$ (US\$175) \\
\hline Washing $\mathrm{MnO}_{2}$ & $2.5 \mathrm{~L}$ (US\$ 0.013) & $2.5 \mathrm{~L}(\mathrm{US} \$ 0.013)$ & $2.5 \mathrm{~L}(\mathrm{US} \$ 0.013)$ \\
\hline Energy consumption ${ }^{* 8}$ & $50 \mathrm{kWh}^{-1}(\mathrm{US} \$ 15)$ & $16.6 \mathrm{kWh}^{-1}(\mathrm{US} \$ 5)$ & $17.7 \mathrm{kWh}^{-1}(\mathrm{US} \$ 5.3)$ \\
\hline Total estimated costs & US\$ 4,925.42 & US\$ $\mathbf{3 , 8 3 5 . 1 4}$ & US\$ 2,354.02 \\
\hline $\mathrm{ZnO}$ & $260 \mathrm{~g}(\mathrm{US} \$ 26)$ & $260 \mathrm{~g}(\mathrm{US} \$ 26)$ & $260 \mathrm{~g}(\mathrm{US} \$ 26)$ \\
\hline $\mathrm{MnO}_{2}$ & $440 \mathrm{~g}(\mathrm{US} \$ 55)$ & $440 \mathrm{~g}(\mathrm{US} \$ 55)$ & $440 \mathrm{~g}(\mathrm{US} \$ 55)$ \\
\hline Sodium salts ${ }^{* 9}$ & $31.50 \mathrm{~kg}$ (US\$ 5,040) & $5.10 \mathrm{~kg}(\mathrm{US} \$ 2,550)$ & $7.70 \mathrm{~kg}(\mathrm{US} \$ 5,005)$ \\
\hline Total value products & US\$ $5,121.00$ & US\$ 2,631.00 & US\$ $5,086.00$ \\
\hline
\end{tabular}

*1 Stirring/heating; *2 Adjust $\mathrm{pH}$ leachate at 2; *3 Acid + water to prepare a $2 \mathrm{~mol} \mathrm{~L}^{-1}$ solution; $* 49 \mathrm{~mol} \mathrm{~L}^{-1} \mathrm{H}_{2} \mathrm{SO}_{4}+$ water to prepare a 5 mol L-1 solution; *5 $\mathrm{Zn}(\mathrm{II})$ precipitation; $* 6 \mathrm{Mn}(\mathrm{II})$ precipitation; *7 Mn(II) oxidation to $\mathrm{MnO}_{2} ; * 8$ Evaporation; *9 See Table 7 .

Table 4). Table 8 presents the estimated costs and the market value of the products obtained in this study (base: $1 \mathrm{~kg}$ active components, 6 vol.\% D2EHPA as extractant, three uses of the extractant solution and $\mathrm{Zn}$ (II) stripping with $5 \mathrm{~mol} \mathrm{~L}^{-1} \mathrm{H}_{2} \mathrm{SO}_{4}$ ).

The revenue of the process decreased following the order $\mathrm{HCOOH}>\mathrm{H}_{2} \mathrm{SO}_{4}>\mathrm{HF}>$. Although formic acid was the most expensive acid employed, the absence of $\mathrm{H}_{2} \mathrm{O}_{2}$ as co-reactant during leaching greatly reduced the cost of the leachant. Despite its losses (Table 7) the recovery of high purity grade sodium formate also increased the revenue because this product presents the highest market value among all salts. The process using $\mathrm{H}_{2} \mathrm{SO}_{4}$ (the cheapest acid) also presented favorable revenue. However, the high water consumption during washing of the insoluble residue increased the costs for $\mathrm{Zn}$ (II) extraction, Zn(II) stripping, Zn(II) precipitation and $\mathrm{Mn}$ (II) precipitation, thus reducing its overall revenue. The process using $\mathrm{HF}$ appears not to be viable. The leachant containing $\mathrm{HF}+\mathrm{H}_{2} \mathrm{O}_{2}$ was the most expensive and the amount of recovered $\mathrm{NaF}$ (Table 7), despite its high commercial value, did not compensate the costs involving the use of this acid.

The contribution of recovered $\mathrm{ZnO}$ and $\mathrm{MnO}_{2}$ to the revenue was very low. Although the contribution of carbon to the revenue was nil, its elimination via controlled burning (before leaching) would impact costs due to high energy consumption. ${ }^{20,24}$ If $\mathrm{MnO}_{2}$ is purified to a grade $>99 \mathrm{wt} \%$ its price increases $5-8$ fold in comparison to the technical grade product. On the other hand, if impurities were brought into the sodium salts, their market value would decrease by a factor of 10-15, making all processes not economically viable. At present, considering other costs (labor, equipment etc.), it is likely that the revenue will partially come from money (price surcharge) that consumers will pay for recycling batteries. ${ }^{24}$

\section{CONCLUSIONS}

Over 95 wt.\% of zinc and manganese were leached from the electroactive components of spent zinc- $\mathrm{MnO}_{2}$ dry cells under mild experimental conditions in the presence of a weak acid and a reductant. Formic acid effectively served the dual role of leachant and reductant as $\mathrm{HF}$ or $\mathrm{H}_{2} \mathrm{SO}_{4}+\mathrm{H}_{2} \mathrm{O}_{2}$ mixtures. Leaching was fastest in the presence of hydrofluoric acid. Precipitation and complexation reactions influenced leaching of minor elements present in the electroactive components. The insoluble matter corresponded to carbon and non-leached elements except for formic acid, where an additional volatile mass was found.

More than 95 wt.\% of $\mathrm{Zn}(\mathrm{II})$ was extracted by D2EHPA in one stage $\left(6 \mathrm{vol} . \%, \mathrm{~A} / \mathrm{O}=1 \mathrm{v} / \mathrm{v}, 25^{\circ} \mathrm{C}\right)$ at $\mathrm{pH} 2$ following the order $\mathrm{HF}$ $>\mathrm{HCOOH}>\mathrm{H}_{2} \mathrm{SO}_{4}$. $\mathrm{Mn}$ (II) extraction from leachates of weak acids was the lowest. Therefore, hydrofluoric or formic acids are alternative leachants for processing spent zinc- $\mathrm{MnO}_{2}$ dry cells. The effect of $\mathrm{pH}$ and D2EHPA concentration on $\mathrm{Zn}$ (II) extraction were the same regardless of the leachant. Extracted $\mathrm{Mn}$ (II) was easily scrubbed with $2 \mathrm{~mol} \mathrm{~L}^{-1}$ leachant. $\mathrm{Zn}(\mathrm{II})$ stripping was only possible using a strong acid $\left(5 \mathrm{~mol} \mathrm{~L}^{-1} \mathrm{H}_{2} \mathrm{SO}_{4}\right.$ ). High purity crystalline sodium salts of the anions of the leachants were obtained after precipitation of $\mathrm{Mn}$ (II) and $\mathrm{pH}$ adjustment of the final solution followed by slow evaporation. Recovery of these salts reduced the amount of final wastes.

\section{SUPPLEMENTARY MATERIAL}

Figure $1 \mathrm{~S}$ presents the general scheme for the recovery of zinc and manganese from spent zinc- $\mathrm{MnO}_{2}$ dry cells after acid leaching in the presence of a reductant. It is available for download at http:// quimicanova.sbq.org.br in pdf format with free access.

\section{ACKNOWLEDGEMENTS}

V. F. Ibiapina and U. S. Florentino acknowledge PIBIC/CNPqUFRJ for the fellowship. We are grateful to $\mathrm{CNPq}$ for financial support. 


\section{REFERENCES AND NOTES}

1. Biswas, R. K.; Karmakar, A. K.; Kumar, S. L.; Waste Manage. 2016, 51, 174.

2. Biswas, R. K.; Karmakar, A. K.; Kumar, S. L.; Waste Manage. 2016, 51 , 149.

3. Xará, S. M.; Delgado, J. N.; Almeida, M. F.; Costa, C. A.; Waste Manage. 2009, 29, 2121.

4. Ippolito, N. M.; Belardi, G.; Medici, F.; Piga, L.; Waste Manage. 2016, $51,182$.

5. Sobianowska-Turek, A.; Szczepaniak, W.; Zabłocka-Malicka, M.; J. Power Sources. 2014, 270, 668

6. Owais, A.; Gepreel, M. A. H.; Ahmed, E.; Hydrometallurgy 2015, 157, 60

7. Karnchanawong, S.; Limpiteeprakan, P.; Waste Manage. 2009, 29, 550.

8. Xará, S. M.; Almeida, M. F.; Costa, C.; Waste Manage. 2015, 43, 460.

9. Belardi, G.; Medici, F.; Piga, L.; J. Power Sources. 2014, 248, 1290.

10. Deep, A.; Sharma, A. L.; Mohanta, G. C.; Kumar, P.; Kim, K. H.; Waste Manage. 2016, 51, 190.

11. Ma, Y.; Cui, Y.; Zuo, X.; Huang, S.; Hu, K.; Xiao, X.; Nan, J.; Waste Manage. 2014, 34, 1793.

12. Komilis, D.; Bandi, D.; Kakaronis, G.; Zouppouris, G.; Sci. Total Environ. 2011, 409, 2555.

13. Câmara, S. C.; Afonso, J. C.; da Silva, L. I. D.; Domingues, N. N.; Alcover Neto, A.; Quim. Nova 2012, 35, 82.

14. Buzatu M.; Săceanu, S.; Petrescu, M. I.; Ghica, G. V.; Buzatu, T.; J. Power Sources 2014, 247, 612.

15. Chen, S.; Guo, G.; Liu, F.; Solid State Ionics 2014, 261, 59.

16. Cruz-Díaz, M. R.; Torres, Y. A.; Caballero, F.; Lapidus, G. T.; González, I.; J. Power Sources 2015, 274, 839.

17. Nogueira, C. A.; Margarido, F.; Hydrometallurgy 2015, 157, 13.

18. Kim, T. H.; Senanayake, G.; Kang, J. G.; Sohn, J. S.; Rhee, K. I.; Lee, S. W.; Shin, S. M.; Hydrometallurgy 2009, 96, 154.

19. Baba, A. A.; Adekola, A. F.; Bale, R. B.; J. Hazard. Mater. 2009, 171, 838.

20. Sayilgan, E.; Kukrer, T.; Civelekoglu, G.; Ferella, F.; Akcil, A.; Veglio, F.; Kitis, M.; Hydrometallurgy 2009, 97, 158.

21. Xin, B.; Jiang, W.; Aslam, H.; Zhang, K.; Liu, C.; Wang, R.; Wang, Y.; Bioresour. Technol. 2012, 106, 147.

22. Quintanilha, C. L.; Afonso, J. C.; Vianna, C. A.; Gante, V.; Mantovano, J. L.; J. Power Sources 2014, 248, 596.

23. Rácz, R.; Ilea, P.; Hydrometallurgy 2013, 139, 116.
24. Ferella, F.; Michelis, I.; Veglio, F.; J. Power Sources. 2008, 183, 805.

25. Balesini, A. A.; Razavizadeh, H.; Zakeri, A.; J. Chem. Eng. 2011, 8, 43.

26. Haghighi, H. K.; Moradkhani. D.; Salarirad, M. M.; Hydrometallurgy, 2015, 154, 9 .

27. Gharabaghi, M.; Irannajad, M.; Azadmehr, A. R.; Physicochem. Probl. Miner. Process. 2013, 49, 233.

28. Vahidi, E.; Raschi, F.; Moradkhami, D.; Miner. Eng. 2009, 22, 204.

29. Lum, K. H.; Stevens, G. W.; Kentish, S. E.; Hydrometallurgy 2014, 142 , 108

30. Larsson, K.; Ekberg, C.; Odegaard-Jensen, A.; Hydrometallurgy 2012, $129-130,35$

31. Jha, M. K.; Kumar V.; Jeong, J.; Lee, J. C.; Hydrometallurgy 2012, 111112,1 .

32. El Dessouky, S. I.; El-Nadi Y. A.; Ahmed, I. M.; Saad, E. A.; Daoud, J. A.; Chem. Eng. Process. 2008, 47, 177.

33. Takeno, N.; Atlas of Eh-pH diagrams, intercomparison of thermodynamic databases. National Institute of Advanced Industrial Science and Technology: Tokyo, 2005

34. Hem, J. D.; Chemical Equilibria and Rates of Manganese Oxidation, The US Government Printing Office: Washington, 1963

35. Li, Y.; Xi, G.; J. Hazard. Mater. 2005, B127, 244.

36. Lurie, J.; Handbook of Analytical Chemistry, $3^{\text {rd }}$ ed., Mir: Moscow, 1978, chap. 3, 6 and 10

37. Feigl, F.; Spot Tests in Inorganic Analysis, Elsevier: Amsterdam, 1958, chap. 3.

38. Formanek, J.; Jandova, J.; Capek, J.; Hydrometallurgy 2013, 138, 100.

39. Lima, T. S.; Campos, P. C.; Afonso, J. C.; Hydrometallurgy 2005, 80, 211.

40. Pinheiro. A. A. S.; Lima, T. S.; Campos, P. C.; Afonso, J. C.; Hydrometallurgy 2004, 74, 77.

41. Liu, X.; Li, S.; Liu, Y.; Cao, Y.; Chin. J. Catal. 2015, 36, 1461

42. Gouvea, L. R.; Morais, C. A.; Miner. Eng. 2010, 23, 492.

43. Roine, A.; HSC Chemistry® ver. 6.1, Outotec Research Oy, Finland, 2010 .

44. Greenwood, N. N.; Earnshaw, A.; Chemistry of the Elements, $2^{\text {nd }}$ ed., Elsevier Butterworth-Heinemann: London, 2010, chap.10.

45. Silva, B. O.; Câmara, S. C.; Afonso, J. C.; Neumann, R.; Alcover Neto, A.; Quim. Nova 2011, 34, 812

46. Alguacil, F. J.; Martinez, S.; J. Chem. Technol. Biotechnol. 2001, 76, 298.

47. Average prices were obtained from quotations provided by five different chemical suppliers in July 2017. 